\title{
Feed efficiency in Mangalarga Marchador foals fed diet supplemented with probiotics or phytase ${ }^{1}$
}

\author{
Raquel Silva de Moura ${ }^{2}$, Eloísa de Oliveira Simões Saliba ${ }^{2}$, Fernando Queiroz de Almeida ${ }^{3}$, \\ Ângela Maria Quintão Lana ${ }^{2}$, Vinícius Pimentel Silva ${ }^{3}$, Adalgiza Souza Carneiro de Rezende ${ }^{2}$ \\ ${ }^{1}$ Pesquisa financiada pela FAPEMIG, com apoio da CAPES e do CNPq. \\ 2 Escola de Veterinária - Universidade Federal de Minas Gerais, Avenida Antônio Carlos, 6627, Campus Pampulha, CP 567, \\ CEP: 30123-970 - Belo Horizonte, Minas Gerais, Brasil. \\ 3 Instituto de Veterinária - Universidade Federal Rural do Rio de Janeiro.
}

ABSTRACT - The objective was to assess the effect of probiotic or phytase supplementation on dry matter intake (DMI), average daily gain (ADG) and feed conversion (FC) in 24 Mangalarga Marchador foals (16 males, 8 females), with $241.6 \pm 23.2$ days of age, and $216.7 \pm 27.8 \mathrm{~kg}$ of body weight $(\mathrm{BW})$. The study lasted 28 days, the first 23 days for diet and handling adaptation, and the last five days for feces collection. The basal diet consisted of Cynodon pasture and pelleted concentrate $(1.2 \mathrm{~kg} / 100 \mathrm{~kg} \mathrm{BW})$, as well as water and mineral salt ad libitum. Treatments groups were assigned as follows: basal diet (control); basal diet $+5 \mathrm{~g}$ /day of live yeast culture $\left(10^{9} \mathrm{CFU} / \mathrm{g}\right.$ of $\mathrm{S}$. cerevisiae); basal diet $+2 \mathrm{~g} / \mathrm{day}$ of live bacteria $\left(10^{8} \mathrm{CFU} / \mathrm{g}\right.$ of $B$. bifidum, E. faecium, L. acidophilus, L. plantarum) and yeast culture $\left(10^{5} \mathrm{CFU} / \mathrm{g}\right.$ of S. cerevisiae); and basal diet $+1250 \mathrm{FTU} /$ day of phytase. Pasture DMI was estimated with an external marker (LIPETM) associated with cecal in situ digestibility of dry matter. All foals were randomized, by replicated, using a $4 \times 2$ factorial, and results were compared using Student t-test, taking into consideration the effect of initial BW as covariate for the percentage DMI per BW. Among foals, DMI varied from 2.4 to $2.8 \%$ BW, with foals supplemented with live bacteria and yeast having lower DMI (total diet and forage). All animals had an ADG of $0.33 \mathrm{~kg} /$ day, and foals supplemented with live bacteria and yeast had FC 32.42 to $43.83 \%$ lower than foals supplemented with phytase or fed only basal diet. The phytase dose of 205 FTU/kg DM in the basal diet had no effects. Probiotic composed of live bacteria and yeast culture improved feed efficiency of forage and can be used as a nutritional strategy to maintain body condition in foals during the dry season.

Key Words: enzymes, horses, Lactobacillus, LIPE ${ }^{\circledR}$, pasture intake, Saccharomyces cerevisiae

\section{Eficiência alimentar de potros da raça Mangalarga Marchador alimentados com dieta suplementada com probióticos ou fitase}

RESUMO - O trabalho foi realizado visando avaliar a influência da suplementação de probióticos ou fitase sobre o consumo diário de matéria seca (CMS), o ganho de peso diário (GPD) e a conversão alimentar (CA) de 24 potros da raça Mangalarga Marchador (16 machos e 8 fêmeas), com 241,6 $\pm 23,2$ dias de idade e 216,7 \pm 27,8 kg de peso vivo (PV). O experimento teve duração de 28 dias: os 23 iniciais para adaptação à dieta e ao manejo e os cinco finais para coleta de fezes. A dieta foi composta por pastagem de Cynodon e concentrado comercial $(1,2 \mathrm{~kg} / 100 \mathrm{~kg} \mathrm{PV})$, além de água e sal mineral à vontade Os tratamentos foram: dieta basal (controle); dieta basal $+5 \mathrm{~g} /$ dia de leveduras vivas $\left(10^{9} \mathrm{UFC} / \mathrm{g}\right.$ de Saccharomyces cerevisiae); dieta basal $+2 \mathrm{~g} /$ dia de bactérias $\left(10^{8} \mathrm{UFC} / \mathrm{g}\right.$ de B. bifidum, E. faecium, L. acidophilus, L. plantarum) e leveduras vivas $\left(10^{5} \mathrm{UFC} / \mathrm{g}\right.$ de $S$. cerevisiae $)$ e dieta basal + fitase (1.250 FTU/dia). Para estimativa do consumo de matéria seca, foram utilizados o indicador externo LIPE $^{\circledR}$ e a técnica de digestibilidade in situ. O delineamento foi inteiramente casualizado, em fatorial $4 \times 2$, e as médias comparadas pelo teste Student, considerando o efeito da covariável PV inicial para porcentagens de CMS por PV. O consumo de matéria seca total dos grupos variou de 2,4 a 2,8\% PV, de modo que os animais sob suplementação com bactérias e leveduras vivas apresentaram menor CMS total e de volumoso. Todos os animais tiveram GPD médio de $0,33 \mathrm{~kg} /$ dia e o grupo sob suplementação com bactérias e leveduras vivas teve conversão alimentar do volumoso 32,42 a 43,83\% menor que a observada no grupo controle e naquele sob suplementação com fitase. A fitase, na dosagem de $205 \mathrm{FTU} / \mathrm{kg}$ de MS da dieta basal, não influenciou os parâmetros avaliados. O probiótico composto por bactérias e leveduras vivas melhorou a eficiência alimentar do volumoso e pode ser utilizado como estratégia nutricional para manutenção da condição corporal de potros durante o período seco.

Palavras-chave: consumo a pasto, enzimas, equinos, Lactobacillus, LIPE ${ }^{\circledR}$, Saccharomyces cerevisiae 


\section{Introduction}

In their first year of life, horses have accelerated body development and, therefore, require an adequate nutritional program in order to grow according to their genetic capacity (Rezende et al., 2000).

Probiotics are live microbial feed supplements which beneficially affect the host animal by improving its intestinal microbial balance (Fuller, 1989). According to Losada \& Olleros (2002), from the nutritional point of view, metabolic activity of probiotic microorganisms contributes to improved digestibility and assimilation of different nutrients, in addition to providing B vitamins to the host. However, there is little research on probiotics in horse nutrition, especially as regards improving digestive function and feed efficiency. Glade (1991) observed increased milk production in lactating mares supplemented with live yeast culture and better performance of their suckling foals. Kim et al. (1991) observed better digestibility of dry matter, crude protein, phosphorus and fiber in mature horses supplemented with S. cerevisiae. Moore et al. (1994) observed large concentrations of cecal protozoa and cellulolytic bacteria, and better digestibility of dry matter in Shetland geldings supplemented with yeast culture. Yuyama et al. (2004) studied the effects of a probiotic composed of five strains of lactobacilli isolated from healthy horses on weight gain in newborn foals, and observed that treated foals grew $6 \%$ more than control animals.

Phytase has been used as a feed additive in pig and chicken diets because of the deleterious effects of phytates in mineral absorption. Microbial phytase production in the hindguts of horses (Pagan, 1990) does not prevent negative effects of phytate in concentrate, because the main location of phosphorus absorption in diets with large amounts of grains occurs in the small intestine (Schryver et al., 1972). Van Doorn et al. (2004) observed effects of phytase on calcium versus phosphorus digestibility when phytatesrich diets were fed to horses. Patterson et al. (2002) supplemented horse diets with phytase and did not observe any effect on dry matter intake and digestibility.

There are limited studies on the effects of probiotics or phytase on intake and feed conversion in foals maintained on pasture. Due to the importance of these nutritional parameters in reducing production costs, the objective of this study was to determine the effects of phytase or probiotic, composed of live yeast culture or live bacteria and yeast culture, as a dietary supplement in Mangalarga Marchador foals and the corresponding effects on daily dry matter intake (DMI), average daily gain (ADG) and feed conversion(FC).

\section{Materials and Methods}

The experiment was carried out at Haras Catuni, located near to Montes Claros, Minas Gerais, Brazil, from July 22 to August 19, 2006. Twenty-four foals of the Mangalarga Marchador breed were used (16 males, 8 females), all from the same stallion, and aged $241.6 \pm 23.2$ days and weighing $216.7 \pm 27.8 \mathrm{~kg} \mathrm{BW}$. Foals were housed in paddocks of 8 hectares with Bermuda grass (Cynodon dactylon $\times$ Cynodon nlemfluensis) and African star grass (Cynodon nlemfluensis) in a continuous grazing system, and with access to waterer, concentrate and mineral salt feeders.

The experiment lasted 28 days; 23 days to adapt the foals to the diet and management, and five days to collect feces. Before beginning the study, all animals were treated for internal and external parasites.

The body condition of each foal was scored (Carol \& Huntington, 1988), and weight was determined at the beginning and end of the experimental period in order to verify that diet was adequate to maintain their nutritional condition.

The basal diet consisted of Cynodon pasture as forage, water and mineral salt (Hiposal 80®; Total Alimentos S./A., Três Corações, Minas Gerais, Brasil) ad libitum, and pelleted concentrate (Table 1). Concentrate was fed twice daily $(7: 30 \mathrm{am}$ and $3: 30 \mathrm{pm})$ in a proportion of $1.2 \mathrm{~kg} /$ $100 \mathrm{~kg} \mathrm{BW}$ (NRC, 1989), determined by the weight at beginning of the experimental period.

All foals were randomized, by replicate, and allocated into four treatments groups, each comprised foals of the same gender and of similar age. In the control group foals were fed only basal diet (control), whereas in the second group they were fed basal diet $+5 \mathrm{~g}$ /day of live yeast culture (Biosaf ${ }^{\circledR}$ Sc 47; Lesaffre Feed Additives, Marcq-en-Baroeul, Nord-Pas-de-Calais, France). The third group of foals was fed basal diet $+2 \mathrm{~g}$ /day of live bacteria and yeast culture (Florafort ${ }^{\circledR}$ aditivo probiótico; Laboratório Vitafort Ind. e Com. de Prod. Veterinários Ltda, Ribeirão Preto, São Paulo, Brasil), and the fourth group received basal diet $+1250 \mathrm{FTU} /$ day of phytase (Natuphos ${ }^{\circledR}$ 5000G; Basf, Aktiengesellschaft, Germany). In the morning, $10 \mathrm{~mL}$ of corn oil was infused orally into each foal as the vehicle for probiotics or phytase.

An external marker (LIPETM; Universidade Federal de Minas Gerais, Belo Horizonte, Minas Gerais, Brazil [Lanzetta et al., 2009]) was infused orally into each foal at $3: 30 \mathrm{pm}$, in one dose of $250 \mathrm{mg} / \mathrm{kg}$, beginning 24 hours before fecal collection. At 3:30 pm feces were collected from the rectum and samples stored in plastic bags, identified by animal and day, and frozen until later analyses. 
Table 1 - Nutritional composition of feed ingredients, on dry matter basis

\begin{tabular}{lccccc}
\hline Feed & Dry matter (\%) & Digestible energy (Mcal/kg DM) & Crude protein (\%) & Lysine (\%) & Oxalate (\%) \\
\hline Forage $^{1}$ & 60.27 & 1.15 & 3.67 & $0.38^{3}$ \\
Concentrate $^{2}$ & 89.97 & 3.65 & 18.89 & $0.87^{4}$ & - \\
\hline Feed & NDF (\%) & ADF (\%) & Lignin (\%) & Ca (\%) \\
\hline Forage $^{1}$ & 82.25 & 45.62 & 9.99 & 0.63 \\
Concentrate $^{2}$ & 31.90 & 11.27 & - & 1.19 \\
\hline
\end{tabular}

1 Cynodon grass.

2 Equisul Lactação 16 Floc ${ }^{\circledR}$ - Total Alimentos S./A.

${ }^{3}$ NRC (1989).

4 Tag guarantee level.

Crude protein:digestible energy ratio in diet: $45.4 \mathrm{~g} \mathrm{CP} / \mathrm{Mcal} \mathrm{DE}$

Calcium:phosphorus ratio in diet: 1.8:1

Calcium:oxalate ratio in forage: $2.1: 1$

Samples of feeds were collected (forage being handplucked; Gardner, 1986) to determine chemical composition. Diet was analyzed for the following: dry matter (DM), crude protein $(\mathrm{CP})$, gross energy $(\mathrm{GE})$, calcium $(\mathrm{Ca})$, phosphorus (P) and oxalate (AOAC, 1995); neutral detergent fiber (NDF), acid detergent fiber (ADF) and lignin (Van Soest et al., 1991). Lignin and oxalate were determined only in forage (Table 1). Feces were analyzed for DM and GE concentrations (AOAC, 1995) and for the external marker LIPETM using infrared spectroscopy (Lanzetta et al., 2009), in the Departamento de Química do Instituto de Ciências Exatas da Universidade Federal de Minas Gerais (UFMG).

From August 24 to 28, 2006, an in situ digestibility assay was carried out in the Laboratório de Pesquisas em Saúde Equina da Universidade Federal Rural do Rio de Janeiro (UFRRJ). One horse, surgically prepared with a cecum cannula (Lowe et al., 1970), was used for two incubations ( 48 hours) of each feed (forage and concentrate) sample. The in situ technique was adapted from Huntington \& Givens (1995). Nylon bags (Tenyl ${ }^{\mathrm{TM}}$ ), with internal area of $6.5 \times 20.0 \mathrm{~cm}$ and pore size $45 \mu$, in a proportion of $20 \mathrm{~g} / \mathrm{cm}^{2}$, as described by Hyslop et al. (1999), were used. Approximately $5.2 \mathrm{~g}$ of each feed, ground to $2 \mathrm{~mm}$, were placed in separate bags and incubated in the cecum for 48 hours. Thereafter, bags were hand-rinsed in water to remove any foreign residues, and oven-dried at $55^{\circ} \mathrm{C}$ for 48 hours. At the end of the assay, bags of similar remaining feed were mixed, homogenized and ground to $1 \mathrm{~mm}$, and analyzed for DM (AOAC, 1995) in the Laboratório de Nutrição Animal da UFMG .

The fecal output was estimated using the external marker LIPETM, in the following formula (Lanzetta et al., 2009):

$$
\text { Fecal output }(\mathrm{kg})=\frac{\operatorname{LIPE}^{\mathrm{TM}} \operatorname{supplied}(\mathrm{g})}{(\mathrm{Ai} / \mathrm{DM})} \times 100
$$

where DM is the dry matter of feces, and Ai represents the logarithmic relationship of absorption intensities of wave lengths bands from $1050 \mathrm{~cm}^{-1} / 1650 \mathrm{~cm}^{-1}$. The Ai was calculated through the formula: $\mathrm{Ai}=\mathrm{A} 1050 / \mathrm{A} 1650$, and $\mathrm{A}=\log \mathrm{I}_{0} / \mathrm{I}$ (where $\mathrm{I}_{0}>$ intensity and $\mathrm{I}<$ intensity).

Losses of DM after in situ cecal incubations were expressed as in situ DM digestibility coefficients determined by bag residues of forage and concentrate feeds, by the formula:

$$
\text { In situ digestibility }(\%)=\frac{1-\text { Residue of bag }(\mathrm{g})}{(\mathrm{I} \times \text { DM Feed })}
$$

where I represents the amount of feed (g) inserted in each bag, and DM Feed is the amount of DM determined at $105^{\circ} \mathrm{C}(\mathrm{AOAC}, 1995)$.

Values of fecal output and DM digestibility (in situ digestibility) were used to estimate DM intake and forage intake of foals, as describe by Saliba (1998):

$$
\text { Intake }(\mathrm{kg} \mathrm{DM})=\frac{\text { Feces output }}{(100-\text { Digestibility })} \times 100
$$

Because daily intake of concentrate was known and in situ digestibility of concentrate was determined, the amount of feces produced from concentrate could be calculated. Then daily DM intake of forage (kg DM/day) was estimated using in situ digestibility of forage, and fecal output from forage was determined by calculating the difference from total fecal output and fecal output of concentrate. Total DM intake was the sum of concentrate and forage intake, expressed as $\mathrm{kg} \mathrm{DM} / \mathrm{day}$. Average weight value of each foal was used to estimate daily DM intake, as BW percentage. Weights at the beginning and end of the experimental period were used to estimate average daily gain (ADG) and feed conversion (FC) of foals. 
The experimental design was a completely randomized in $4 \times 2$ factorial, and means were compared using the Student t-test $(\mathrm{P}<0.05)$. The effect of covariate initial BW was considered in the means of total DMI and forage intake per BW percentages.

\section{Results and Discussion}

The in situ DM digestibility of concentrate and of forage was 84.16 and $33.36 \%$, respectively. Average total fecal output of foals was $2.68 \mathrm{~kg} / \mathrm{animal} /$ day. The study was carried out during in the dry season, and low digestibility of forage was attributed to increased lignin in mature grasses (Hacker \& Minson, 1981). Araújo et al. (2000), evaluating Coast-cross hay with similar lignin concentration $(9.1 \%)$, observed low DM digestibility (43.02\%) using the total feces collection method. This was even higher than observed in the present study.

The NRC (1989) advocated, in weaning foals, a daily feed intake ranging from 2.0 to $3.5 \% \mathrm{BW}$ for feeds with
$90 \% \mathrm{DM}$, or DMI varying from 1.8 to $3.2 \% \mathrm{BW}$. In the present study, the average DMI, as BW percentage, was inside those limits (Table 2), and foals supplemented with live bacteria and yeast presented values closer to the recommended minimum. This occurs as a function of lower forage intake among foals in this group as compared with foals supplemented with live yeast or phytase. Hoskin $\&$ Gee (2004) suggested that control of forage intake in growing horses occurs mainly as a function of digestible energy intake. Therefore, the probable increase of microbiota in the large intestine promoted by live bacteria and yeast may enhance the energy supplied through the diet, and result in low feed intake.

Average daily gain (ADG) in foals during the experimental period (Table 3) showed no differences $(\mathrm{P}>0.05)$ among treatment groups. Although foals supplemented with live bacteria and yeast have lower feed intake than others, they maintained similar ADG during the period, demonstrating that this probiotic is beneficial in forage utilization by foals.

Table 2 - Daily dry matter intake estimate of diet (DMI total) and forage (DMI forage)

\begin{tabular}{|c|c|c|c|c|c|c|}
\hline \multirow[t]{2}{*}{ Diet } & \multicolumn{3}{|c|}{ DMI total ${ }^{1}$} & \multicolumn{3}{|c|}{ DMI forage ${ }^{2}$} \\
\hline & kg/day (\% BW) & $\mathrm{kg} /$ day $(\% \mathrm{BW})$ & $\mathrm{kg} /$ day $(\% \mathrm{BW})$ & kg/day (\% BW) & $\mathrm{kg} /$ day $(\% \mathrm{BW})$ & $\mathrm{kg} /$ day $(\% \mathrm{BW})$ \\
\hline Control & $5.74 \quad(2.51)$ & $5.55(2.73)$ & $5.67 \mathrm{AB}(2.58 \mathrm{AB})$ & $3.31(1.46)$ & $3.48 \quad(1.72)$ & $3.36 \mathrm{AB}(1.55 \mathrm{AB})$ \\
\hline Probiotic yeast & $5.77 \quad(2.61)$ & $5.91(2.89)$ & $5.82 \mathrm{AB}(2.70 \mathrm{~A})$ & $3.43(1.56)$ & $3.84(1.88)$ & $3.57 \mathrm{AB}(1.66 \mathrm{~A})$ \\
\hline Probiotic bacteria and yeast & $5.77(2.36)$ & $4.92(2.44)$ & $5.49 \mathrm{~B} \quad(2.39 \mathrm{~B})$ & $3.25(1.33)$ & $2.76(1.37)$ & $3.09 \mathrm{~B}(1.35 \mathrm{~B})$ \\
\hline
\end{tabular}

${ }^{1} \mathrm{CV}=11.07 \%(\mathrm{~kg} /$ day $)$ e $10.16 \%(\% \mathrm{BW})$.

${ }^{2} \mathrm{CV}=17.35 \%(\mathrm{~kg} /$ day $)$ e $17.46 \%(\% \mathrm{BW})$

Means, with different capital letters within columns and small letters within rows, $\operatorname{differ}(\mathrm{P}<0.05)$ by Student t-test.

Table 3 - Average daily gain (ADG) and feed conversion of total diet (FC total) and of forage (FC forage) and concentrate (FC concentrate)

\begin{tabular}{|c|c|c|c|c|c|c|}
\hline \multirow[b]{2}{*}{ Diet } & \multicolumn{3}{|c|}{$\mathrm{ADG}$} & \multicolumn{3}{|c|}{ FC total } \\
\hline & Colt (kg/day) & Filly (kg/day) & Mean (kg/day) & Colt & Filly & Mean \\
\hline Control & 0.30 & 0.31 & $0.30 \mathrm{~A}$ & 22.94 & 18.24 & $21.38 \mathrm{~A}$ \\
\hline Probiotic yeast & 0.29 & 0.46 & $0.35 \mathrm{~A}$ & 22.43 & 12.78 & $19.21 \mathrm{~A}$ \\
\hline Probiotic bacteria and yeast & 0.34 & 0.32 & $0.33 \mathrm{~A}$ & 17.51 & 15.84 & $16.96 \mathrm{~A}$ \\
\hline Phytase & 0.40 & 0.21 & $0.33 \mathrm{~A}$ & 16.72 & 33.32 & $22.25 \mathrm{~A}$ \\
\hline Mean & $0.33 \mathrm{a}$ & $0.32 \mathrm{a}$ & 0.33 & $19.90 \mathrm{a}$ & $20.05 \mathrm{a}$ & 19.95 \\
\hline \multirow[t]{2}{*}{ Diet } & \multicolumn{3}{|c|}{$\mathrm{FC}$ forage } & \multicolumn{3}{|c|}{ FC concentrate } \\
\hline & Colt & Filly & Mean & Colt & Filly & Mean \\
\hline Control & $13.35 \mathrm{Aa}$ & $11.28 \mathrm{Aa}$ & $12.66 \mathrm{~A}$ & 9.59 & 6.97 & $8.72 \mathrm{~A}$ \\
\hline Probiotic yeast & $13.20 \mathrm{Aa}$ & $8.26 \mathrm{Aa}$ & $11.56 \mathrm{AB}$ & 9.23 & 4.52 & $7.66 \mathrm{~A}$ \\
\hline Probiotic bacteria and yeast & $9.92 \mathrm{Aa}$ & $8.82 \mathrm{Aa}$ & $9.56 \mathrm{~B}$ & 7.59 & 7.02 & $7.40 \mathrm{~A}$ \\
\hline Phytase & $9.86 \mathrm{Aa}$ & $21.51 \mathrm{Bb}$ & $13.75 \mathrm{~A}$ & 6.85 & 11.81 & $8.51 \mathrm{~A}$ \\
\hline Mean & $11.59 \mathrm{a}$ & $12.47 \mathrm{a}$ & 11.88 & $8.31 \mathrm{a}$ & $7.58 \mathrm{a}$ & 8.07 \\
\hline
\end{tabular}

$\mathrm{CV}=35.59 \%$ (ADG); 39.71\% (FC total); 37.99\% (FC forage); $45.00 \%$ (FC concentrate).

Means, with different capital letters within columns and small letters within rows, differ $(\mathrm{P}<0.05)$ by Student t-test 
Feed conversion (FC) of total diet and concentrated feed (Table 3 ) were similar among groups $(\mathrm{P}>0.05)$. Additives may not have improved FC of concentrate because probiotics mainly affect fiber degradation, by an increase of the hindgut microbiota. The hypothesis was confirmed through better efficiency in FC of forage in foals supplemented with live bacteria and yeast compared to foals supplemented with phytase or control diet. Foals supplemented with live yeast presented intermediate $\mathrm{FC}$ values. These results agreed with the statements of Kim et al. (1991), Moore et al. (1994) and Losada \& Olleros (2002), that probiotics improve the quality of microbiota in the large intestine, and consequently enhance the digestibility of nutrients and animal performance.

Feed conversion of forage in foals supplemented with live bacteria and yeast were 32.43 to $43.83 \%$ lower than in foals supplemented with phytase or the control diet, and foals supplemented with live yeast culture presented intermediate values (Table 3 ). Within this probiotic were two bacteria from the genus Lactobacillus (L. acidophilus and L. plantarum); and, according to Yuki et al. (2000), it is the predominant bacterium of equine digestive microbiota. This may explain the increased effects of probiotic composed of live bacteria and yeast compared to probiotic composed only of yeast culture. Yuyama et al. (2004) stated that the use of equine-specific microorganisms is an important requisite to obtaining favorable results with probiotics. The results of the present study agree with Vanbelle et al. (1990), who affirmed that the use of appropriate strains of viable lactic acid bacteria in calf, pig and domestic bird diets improve performance of those animals.

There was an interaction between gender and diets in FC of forage. Fillies supplemented with phytase had poorer FC than colts of same group and fillies of other treatment groups. As there was no interaction between DMI and ADG, it is possible that individual variation among research animals was responsible for those results, even though foals were homogeneous and equally distributed according to age and sex.

Phytase may improve feed efficiency in animals as a result of more available phosphorus, and consequently control intestinal $\mathrm{pH}$, buffering volatile fatty acids produced by cellulolytic bacteria (Schyrer et al., 1972). The dose of phytase supplied to foals was $544 \mathrm{FTU} / \mathrm{kg}$ DM of concentrate (in agreement with laboratory recommendations), or $205 \mathrm{FTU} / \mathrm{kg}$ DM of total diet. No significant differences in DMI, ADG and FC were observed in comparison to foals fed the control diet, in agreement with Paterson et al. (2002) who did not observe differences in DM intake of horses supplemented with phytase in dosages of 0,300, 600 and $900 \mathrm{FTU} / \mathrm{kg}$ of diet.

\section{Conclusions}

Probiotics composed of live lactic acid bacteria and yeast improve forage utilization during the dry season and can be used as part of the nutritional strategy to maintain body condition in Mangalarga Marchador foals.

Phytase supplementation of 205 FTU/kg DM of diet (or $544 \mathrm{FTU} / \mathrm{kg} \mathrm{DM}$ of concentrate) did not affect foals performance, although further research needs to be conducted concerning the level of supplemental phytase added to the diet and its enzymatic stability in the equine digestive tract.

Appropriate probiotics for horses require futher microbiological evaluations of microorganisms added in commercial products (minimum concentration, viability and antagonism among species).

\section{Acknowledgements}

The authors thank Fundação de Amparo a Pesquisa do Estado de Minas Gerais (FAPEMIG) for financial support; Haras Catuni for supplying foals and farm workers; Total Alimentos S./A. for concentrate; Lesaffre Feed Additives and Laboratório Vitafort Ind. e Com. de Produtos Veterinários Ltda. for probiotics; Basf for phytase; and Rose M. Kastelic for translation assistance.

\section{Literature Cited}

ARAÚJO, K.V.; LIMA, J.A.F.; FIALHO, E.T. et al. Comparison among the internal markers and the total collection method in the determination of the forage nutrients digestibilities in equine. Revista Brasileira de Zootecnia, v.29, n.3, p.745-751, 2000 .

ASSOCIATION OF OFFICIAL ANALYTICAL CHEMISTRY AOAC. Official methods of analysis. 16.ed. Arlington: AOAC International, 1995. 1025p.

CAROL, C.L.; HUNTINGTON, P.J. Body condition scoring and weight estimation of horses. Equine Veterinary Journal, v.20, n.1, p.41-45, 1988.

FULLER, R. Probiotic in man and animals - a review. Journal of Applied Bacteriology, v.66, p.365-378, 1989.

GARDNER, A.L. Técnicas de pesquisa em pastagens e aplicabilidade de resultados em sistemas de produção. Brasília: II CA/Embrapa, 1986. 197p.

GLADE, M.J. Effects of dietary yeast culture supplementation of lactating mares on the digestibility and retention of the nutrients delivered to nursing foals via milk. Equine Veterinary Science, v.11, n.6, p.323-329, 1991.

HACKER, J.B.; MINSON, D.J. The digestibility of plants parts. Herbage Abstracts, v.51, n.9, p.459-482, 1981.

HOSKIN, S.O.; GEE, E.K. Feeding value of pasture for horses. New Zealand Veterinary Journal, v.52, n.6, p.332-341, 2004 .

HUNTINGTON, J.A.; GIVENS, D.L. The in situ technique for studying the rumen degradation of feeds: a review of the procedure. Nutrition Abstract and Review (Series B), v.65, n.2, p.63-93, 1995 
HYSLOP, J.J.; STEFANSDOTTIR, G.J.; McLEAN, B.M.L. et al. In situ incubation sequence and its effect on degradation of food components when measured in the caecum of ponies. Animal Science, v.69, p.147-155, 1999.

KIM, S.M.; KIM, C.M.; LEE, H.K. et al. Evaluation of nutrient values of some feedstuffs, and the effects of yeast culture supplementation on digestibilities of nutrients and blood parameter in horse. Korean Journal Animal Nutrition Feeding, v.15, n.5, p.272-280, 1991.

LANZETTA, V.A.S.; REZENDE, A.S.C. et al. Validation of Lipe ${ }^{\mathrm{TM}}$ as method to evaluate the apparent digestibility of nutrients in equines. Revista Brasileira de Zootecnia, v.38, n.1, p.69-74, 2009.

LOSADA, M.A.; OLLEROS, T. Towards a healthier diet for the colon: the influence of fructooligosaccharides and lactobacilli on intestinal health. Nutrition Research, v.22, n.1-2, p.71-84, 2002 .

LOWE, J.E.; HINTZ, H.F.; SCHRYVER, H.F.A. A new technique for long-term cecal fistulation in ponies. American Journal of Veterinarian Research, v.31, n.6, p.1109-1111, 1970.

MOORE, B.E.; NEWMAN, K.E.; SPRING, P. et al. Effect of yeast culture (Yea-Sacc ${ }^{1026}$ ) on microbial populations and digestion in the cecum and colon of the equine. Journal of Animal Science, v. 72, p.252-253, 1994 (suppl. 1).

NATIONAL RESEARCH COUNCIL - NRC. Nutrient requeriments of horses. 5.ed. Washington, D.C.: National Academy of Science, 1989. 100p.

PAGAN, J.D. Effect of yeast culture supplementation on nutrient digestibility in mature horses. Journal of Animal Science, v.68, p.371, 1990 (suppl.).

PATTERSON, D.P.; COOPER, S.R.; FREEMAN, D.W. et al. Effects of varying levels of phytase supplementation on dry matter and phosphorus digestibility in horses fed a common textured ration. Journal of Equine Veterinary Science, v.22, n.10, p.456-459, 2002.

REZENDE, A.S.C.; SAMPAIO, I.B.M.; LEGORRETA, G.L. et al Effect of two diferent nutritional programs on orthopedic alterations in Mangalarga Marchador foals. Journal of Equine Veterinary Science, v.20, n.10, p.651-656, 2000.

SALIBA, E.O.S. Caracterização química e microscópica das ligninas dos resíduos de milho e de soja expostas à degradação ruminal e seu efeito sobre a digestibilidade dos carboidratos estruturais. 1998. 252f. Tese (Doutorado em Zootecnia) Universidade Federal de Minas Gerais, Belo Horizonte, 1998.

SCHRYVER, H.G.; HINTZ, H.F.; GRAIG, P.H. et al. Site of phosphorus absorption from the intestine of the horse. Journal of Nutrition, v.102, n.1, p.143-148, 1972.

Van SOEST, P.J.; ROBERTSON, J.B.; LEWIS, B.A. Methods for dietary fiber, neutral detergent fiber and nonstarch polysaccharides in relation to animal nutrition. Journal of Dairy Science, v.74, n.10, p.3583-3597, 1991.

Van DOORN, D.A.; EVERTS, H.; WOUTERSE, H. et al. The apparent digestibility of phytase phosphorus and the influence of supplemental phytase in horses. Journal of Animal Science, v. 82, n.6, p. $1756-1763,2004$

VANBELlE, M.; TELLER, E.; FOCANT, M. Probiotics in animal nutrition: a review. Archives of Animal Nutrition, v.40, n.7, p.543-567, 1990.

YUKI, N.; SHIMAZAKI, T.; KUSHIRO, A. et al. Colonization of the stratified squamous epithelium of the non-secreting area of horse stomach by lactobacilli. Applied Environment Microbiology, v.66, p.5030-5034, 2000

YUYAMA, T.; YUSA, S.; TAKAI, S. et al. Evaluation of a hostspecific Lactobacillus probiotic in neonatal foals. The International Journal Applied Research in Veterinary Medicine, v.2, n.1, p. 26-33, 2004 